\title{
GAMBARAN TINGKAT STRES PASIEN DIABETES MELLITUS
}

\author{
Livana $\mathbf{P H}^{1}$, Indah Permata Sari ${ }^{1}$, Hermanto ${ }^{1}$ \\ ${ }^{1}$ Program studi Ners, Sekolah Tinggi Ilmu Kesehatan Kendal \\ livana.ph@gmail.com
}

\begin{abstract}
Abstrak
Diabetes Mellitus merupakan kelainan metabolik yang ditandai dengan kenaikan kadar gula darah, akibat adanya kelainan sekresi insulin, kerja insulin atau keduanya. Pasien Diabetes Mellitus harus melakukan terapi pengelolaan sepanjang hidupnya baik secara farmakologis maupun non farmakologis untuk mencegah terjadinya komplikasi dan mengontrol kestabilan kadar gula darahnya. Terapi tersebut dapat menimbulkan suatu dampak tertentu, baik secara fisik maupun secara psikologis. Salah satu dampak psikologis yang dapat dirasakan oleh pasien Diabetes Mellitus adalah stres. Penelitian ini bertujuan untuk mengetahui gambaran tingkat stres pada pasien Diabetes Mellitus di wilayah dokter keluarga Djazariyah Kabupaten Kendal. Metode deskriptif kuantitatif. Alat ukur yang digunakan berupa kuesioner Depression Anxiety Stres Scale yang terdiri dari 42 pertanyaan. Sampel berjumlah 37 responden. Sebagian besar pasien Diabetes Mellitus mengalami stres ringan. Peneliti memberikan saran bagi peneliti selanjutnya untuk menggunakan kuesioner Depression Anxiety Stres Scale yang telah dimodifikasi disetiap pertanyaannya, agar mempermudah responden dalam menjawab.
\end{abstract}

Kata kunci: Stres pada pasien Diabetes Mellitus.

\begin{abstract}
The description of stress levels in Diabetes Mellitus patients. Diabetes Mellitus is a metabolic abnormality characterized by elevated blood sugar levels, due to an abnormality of insulin secretion, insulin work or both. Diabetes Mellitus patients should take life-long management therapy both pharmacologically and nonpharmacologically to prevent complications and control the stability of their blood sugar levels. The therapy can have a certain impact, both physically and psychologically. One of the psychological effects that can be felt by Diabetes Mellitus patients is stress. This study aims to determine the description of stress levels in Diabetes Mellitus patients in the area of Djazariyah family doctor Kendal District. Quantitative descriptive method. The measuring tool used is a questionnaire of Depression Anxiety Stress Scale consisting of 42 questions. The sample was 37 respondents. Most Diabetes Mellitus patients experience mild stress. Researchers provide suggestions for further researchers to use the questionnaire of Depression Anxiety Stress Scale that has been modified in each question, in order to facilitate respondents in answering.
\end{abstract}

Keywords: Stress in Diabetes Mellitus clients

\section{Pendahuluan}

Diabetes Mellitus (DM) merupakan sekelompok kelainan metabolik yang ditandai dengan kenaikan kadar gula darah akibat adanya kelainan sekresi insulin, kerja insulin atau keduanya (Gustaviani, 2006). Penyakit DM menjadi induk berbagai macam penyakit, sehingga pasien DM akan mengalami dampak berupa perubahan- perubahan fisik maupun psikologis. Angka prevalensi DM selalu meningkat dari tahun ke tahun. Data World Health Organization (WHO), diketahui terdapat 422 juta pasien DM di dunia (WHO, 2016). Prevalensi DM di Indonesia berdasarkan Riset Kesehatan
Daerah (Riskesdas) terus mengalami kenaikan yaitu dari 1,1\% pada tahun 2007 menjadi 2,1\% pada tahun 2013 (Riskesdas, 2013). Prevalensi DM di Jawa Tengah juga mengalami kenaikan, Dinas Kesehatan (Dinkes) Jawa Tengah melaporkan terdapat $13,6 \%$ pasien DM pada tahun 2013, pada tahun 2014 meningkat menjadi $14,96 \%$, dan pada tahun 2015 kembali meningkat menjadi 16,69\% (Dinkes Jateng, 2015). Kabupaten Kendal memiliki angka prevalensi DM yang cukup tinggi yaitu mencapai 2.954 orang.

Terapi pengelolaan yang dilakukan dengan baik akan membantu pasien DM 
untuk hidup seperti orang normal pada umumnya dan memiliki umur yang lebih panjang (Sutedjo, 2010). Perkumpulan Endokrinologi Indonesia (Perkeni) membagi dua macam terapi yang harus dilakukan oleh pasien DM selama hidupnya yaitu secara farmakologis berupa pemberian obat-obatan dan non farmakologis berupa pengaturan diet, latihan jasmani, dan edukasi (Perkeni, 2011). Terapi tersebut dapat menimbulkan suatu dampak tertentu, baik secara fisik maupun psikologis (Solichah, 2009). Dampak secara fisik yang biasanya dirasakan oleh pasien DM berupa perubahan berat badan, perubahan nafsu makan, sering mengalami nyeri, keletihan, dan gangguan tidur, sedangkan secara psikologis pasien DM akan mengalami stres, cemas, takut, sering merasa sedih, merasa tidak ada harapan, tidak berdaya, tidak berguna, dan putus asa (Tjokroprawiro, 2011). Permasalahan emosional yang sering dialami pasien DM antara lain penyangkalan terhadap penyakitnya sehingga mereka tidak patuh dalam menerapkan pola hidup yang sehat, mudah marah dan frustrasi karena banyaknya pantangan atau merasa telah menjalani berbagai terapi tetapi tidak terjadi perubahan kadar gula darah yang membaik, takut terhadap komplikasi dan resiko kematian, jenuh meminum obat, atau bahkan mengalami depresi (Semiardji, 2009).

Penyakit DM cenderung menimbulkan dampak yang bersifat negatif, tetapi penyakit ini juga dapat memberikan dampak yang positif seperti adanya psychological well-being (kesejahteraan psikologis) pada pasien DM yang meningkat. Kesejahteraan psikologis merupakan suatu keadaan seseorang yang mampu menerima kekuatan dan kelemahan dirinya, membina hubungan positif dengan orang lain, mengarahkan perilakunya sendiri, mengembangkan potensi diri secara terus menerus, menguasai lingkungan, dan memiliki tujuan dalam kehidupannya (Rfyy \& Singer, 2006).
Kesejahteraan psikologis yang baik pada pasien DM akan memberikan motivasi untuk meningkatkan kualitas hidupnya.

Upaya pencegahan terjadinya DM dapat dilakukan oleh semua orang, sehingga dapat meminimalkan munculnya dampak-dampak yang dapat memperburuk kondisi kesehatan. Orang yang memiliki resiko DM, pasien DM tanpa komplikasi dan pasien DM dengan komplikasi harus melakukan pencegahan dengan cara pencegahan primer, sekunder maupun tersier. Pemantauan kadar glukosa darah merupakan salah satu upaya pencegahan terjadinya DM tersebut (Baradero, Dayrit, \& Siswadi, 2009). Pemantauan kadar glukosa darah rutin pada pasien DM menjadi bagian yang penting dari pengendalian penyakit (Kristiana, 2012).

Kepatuhan pasien DM untuk melakukan pemantauan glukosa darah harus melibatkan partisipasi atau peran dari keluarga pasien DM. Keluarga pasien DM berperan sebagai pemberi asuhan keperawatan secara informal yaitu dengan memberikan kesempatan kepada pasien DM untuk berlatih mengelola dirinya sendiri terutama untuk melakukan pemeriksaan kadar glukosa darahnya. Masalah akan muncul pada pasien DM yang tidak patuh dengan ajakan keluarganya untuk memeriksakan kadar glukosa darahnya, dan keluarga hanya memotivasi tetapi tidak mendampingi pemeriksaan yang harus dilakukan di laboratorium, rumah sakit, klinik, puskesmas, atau melakukan pemeriksaan kadar glukosa darah secara mandiri. Pasien DM yang belum menyadari pentingnya dan manfaat melakukan pemantauan kadar glukosa darah secara rutin juga menjadi penyebab pasien DM tidak patuh terhadap ajakan keluarganya untuk melakukan pemeriksaan tersebut (Sari, Susanti, dan Sumawati, 2014).

Hasil penelitian Tamara, Bayhakki, dan Nauli (2014) menunjukkan ada hubungan antara dukungan keluarga dan kualitas hidup pasien DM tipe 2 di RSUD Arifin Achmad Provinsi Riau. Dukungan 
keluarga yang diberikan dalam bentuk emosional, instrumental, penghargaan dan informasi dapat memberikan rasa nyaman dan dapat meningkatkan motivasi pasien DM dalam menjalani pengobatan dan perawatan diri. Hasil penelitian Priharianto, Maliya, dan Rosyid (2014), sebanyak 23,6\% pasien DM yang mendapat dukungan keluarga yang kurang, $18 \%$ diantaranya tidak teratur kontrol kadar gula darah dan 5,6\% lainnya teratur melakukan kontrol kadar gula darah, sebanyak $51,7 \%$ pasien DM mendapat dukungan yang cukup, 22,5\% diantaranya tidak teratur dan $29,2 \%$ lainnya teratur melakukan kontrol kadar gula darah, sebanyak $24,7 \%$ pasien DM mendapat dukungan yang baik dari keluarga, 7,9\% diantaranya tidak teratur dan $16,9 \%$ lainnya teratur melakukan kontrol kadar gula darah.

Hasil studi pendahuluan yang dilakukan pada pasien DM yang tergabung dalam Program Pengelolaan Penyakit Kronis (Prolanis) di wilayah kerja Dokter keluarga Djazariyah Kabupaten Kendal pada bulan September 2016 terdapat 54 pasien DM. Rata-rata pasien DM yang tergabung dalam Prolanis tersebut adalah perempuan. Hasil wawancara didapatkan bahwa 2 dari 3 pasien DM tidak melakukan kontrol kadar gula darah secara rutin karena terkendala biaya, dan tidak ada anggota keluarga yang mengantar. Mereka mengalami perubahan selera makan, sering merasa letih, sering merasa mengantuk, mengalami gangguan tidur, merasa sedih, merasa tidak berdaya, cemas, dan takut apabila penyakitnya dapat menimbulkan penyakit yang lain.

\section{Metode}

Penelitian ini menggunakan metode penelitian kuantitatif deskriptif. Penelitian kuantitatif merupakan penelitian yang menekankan pada fenomena-fenomena objektif yang dikaji secara kuantitatif (Hamdi, Bahruddin, 2014). Penelitian deskriptif merupakan penelitian yang mendeskripsikan sebuah fenomena atau masalah disebuah tempat misalnya komunitas, puskesmas, rumah sakit, dan lain-lain (Lapau, 2012). Penelitian ini dilakukan di wilayah kerja Dokter keluarga Djazariyah Kabupaten Kendal. Populasi merupakan sekumpulan individu yang tinggal di suatu wilayah yang sama, atau sekumpulan individu (objek) yang memiliki karakteristik yang sama (Chandra, 2008). Sampel penelitian ini yaitu pasien DM yang tercatat mengikuti kegiatan Prolanis terakhir pada bulan September 2016 di wilayah kerja Dokter keluarga Djazariyah Kabupaten Kendal, sebanyak 37 orang. Penentuan sampel dari suatu populasi yang dijadikan subjek penelitian, dilakukan dengan menggunakan sebuah teknik atau cara yang disebut dengan teknik sampling. Teknik sampling yang digunakan dalam penelitian ini yaitu purposive sampling. Teknik purposive sampling merupakan suatu teknik untuk menetapkan sampel dengan cara memilih sampel di antara populasi yang sesuai dengan kehendak peneliti, tujuan dan masalah penelitian, sehingga sampel tersebut dapat mewakili karakteristik populasi yang ada (Nursalam, 2008).

\section{Hasil}

Karakteristik pasien DM disajikan pada tabel 1, sedangkan gambaran tingkat stres disajikan pada gambar 1 berikut ini. 
Gambar 1.

Tingkat stres pasien DM

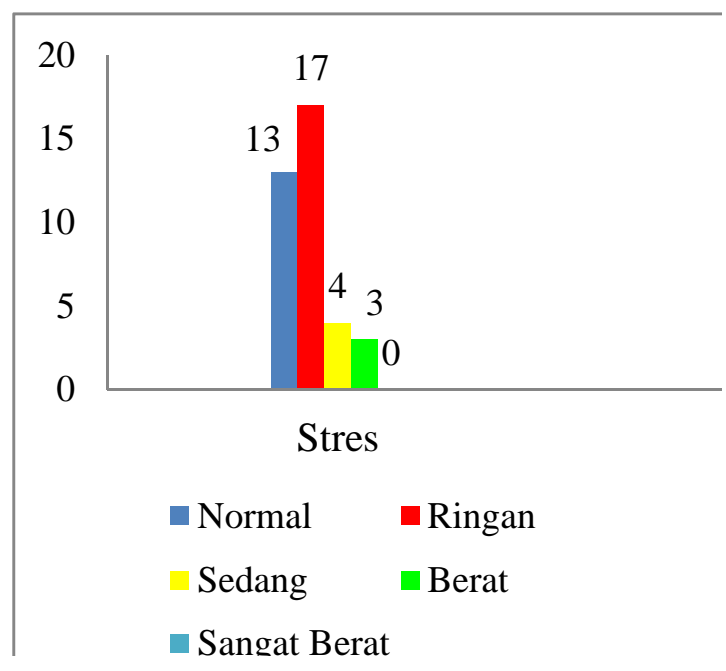

Tabel 1.

Karakteristik pasien DM $(\mathrm{n}=37)$

\begin{tabular}{|c|c|c|}
\hline \multirow{2}{*}{$\begin{array}{lll} & \text { Karakteristik } \\
\text { a. Usia: }\end{array}$} & \multirow[t]{3}{*}{$\mathrm{f}$} & \multirow[t]{2}{*}{$\%$} \\
\hline & & \\
\hline 1) $18-25$ tahun & & 0 \\
\hline 2) $25-60$ tahun & 20 & 54,0 \\
\hline 3) > 60 tahun & 17 & 46,0 \\
\hline b. Jenis Kelamin: & & \\
\hline 1) Laki-laki & 17 & 46,0 \\
\hline 2) Perempuan & 20 & 54,0 \\
\hline c. Tingkat Pendidikan: & & \\
\hline 1) Tidak sekolah & 3 & 8,0 \\
\hline 2) $\mathrm{SD}$ & 6 & 16,0 \\
\hline 3) SMP & 10 & 27,0 \\
\hline 4) SMA & 13 & 35,0 \\
\hline 5) Perguruan Tinggi & 5 & 14,0 \\
\hline d. Pekerjaan: & & \\
\hline 1) Tidak bekerja & 22 & 59,0 \\
\hline 2) Bekerja & 15 & 41,0 \\
\hline e. Tingkat Ekonomi: & & \\
\hline 1) < Rp. 1.639 .600 & 16 & 43,0 \\
\hline 2) > Rp. 1.639 .600 & 13 & 35,0 \\
\hline 3) $=$ Rp. 1.639 .600 & 8 & 22,0 \\
\hline f. Status Perkawinan: & & \\
\hline 1) Belum menikah & 3 & 8,0 \\
\hline 2) Menikah & 23 & 62,0 \\
\hline 3) Bercerai & 11 & 30,0 \\
\hline Lama Menderita DM: & & \\
\hline 1) $<6$ bulan & 1 & 3,0 \\
\hline 2) $>6$ bulan -5 tahun & 13 & 35,0 \\
\hline 3) $>5$ tahun & 23 & 62,0 \\
\hline
\end{tabular}

\section{Pembahasan}

Hasil penelitian menunjukkan terdapat 20 responden $(54,0 \%)$ berusia $25-$ 60 tahun. Hasil penelitian ini sejalan dengan penelitian yang dilakukan oleh Sunjaya (2009), bahwa 47,5\% kelompok usia yang paling banyak menderita DM adalah kelompok usia 45-52 tahun. Proses penuaan pada kelompok usia tersebut menyebabkan berkurangnya kemampuan sel beta pankreas dalam memproduksi insulin, selain itu terdapat penurunan aktivitas mitokondria di sel-sel otot sebesar $35 \%$, hal ini berhubungan dengan kenaikan 
kadar lemak di otot sebesar $30 \%$ dan memicu terjadinya resistensi insulin. Hasil penelitian yang dilakukan oleh Jelantik dan Haryati (2014), menunjukkan bahwa terdapat hubungan antara usia dengan kejadian DM tipe 2 yaitu sebagian besar responden memiliki umur lebih dari 40 tahun. Hasil penelitian Yusra (2010), mengatakan bahwa dengan bertambahnya usia pada seseorang, maka dapat menimbulkan suatu perubahan baik secara fisik, psikologis, maupun intelektual. Perubahan tersebut dapat menyebabkan kerentanan terhadap berbagai penyakit dan dapat menimbulkan kegagalan dalam mempertahankan homeostatis terhadap stres.

Hasil penelitian menunjukkan terdapat 20 responden $(54,0 \%)$ berjenis kelamin perempuan. Hasil penelitian ini sejalan dengan penelitian yang dilakukan oleh Zainuddin, Wasisto, dan Herlina (2015), dalam penelitiannya terdapat 53,3\% pasien DM berjenis kelamin perempuan. Perempuan lebih beresiko terkena DM, karena secara fisik perempuan memiliki peluang kenaikan Indeks Massa Tubuh (IMT) yang lebih besar, selain itu sindroma siklus bulanan (premenstrual syndrome) dan pasca menopause membuat distribusi lemaklemak tubuh menjadi mudah terakumulasi. Pendapat Taylor (2008), mengatakan bahwa perubahan hormonal seperti penurunan estrogen dan progesteron akibat menopause dapat mempengaruhi kadar gula darah. Hasil penelitian Hasanuddin, Kristofel, Mahatrisni, Winasis dan Satrio (2011), menyatakan bahwa perempuan dengan DM dapat mengalami penurunan kualitas hidup seperti mengalami gangguan dalam beraktivitas, mengalami perubahan peran dan perubahan kondisi fisik, hal ini akan memicu timbulnya ansietas, stres, dan depresi. Penelitian tersebut tidak sejalan dengan penelitian yang dilakukan oleh Yusra (2010), dalam penelitiannya menunjukkan bahwa tidak ada hubungan antara jenis kelamin dengan kualitas hidup, laki-laki dan perempuan memiliki kemampuan yang sama dalam menyelesaikan masalah, laki-laki dan perempuan menyikapi dan berperilaku sesuai dengan yang diharapkan untuk mengelola penyakit yang dideritanya.

Hasil penelitian menunjukkan terdapat 13 responden $(35,0 \%)$ berpendidikan Sekolah Menengah Atas. Hasil penelitian ini sejalan dengan penelitian yang dilakukan oleh Yusra (2010), bahwa terdapat hubungan antara tingkat pendidikan dengan kualitas hidup. Pendapat dari Notoatmodjo (2007), mengatakan bahwa tingkat pendidikan akan menentukan mudah tidaknya seseorang dalam menerima dan memahami pengetahuan yang diberikan. Pendapat yang sama juga dikemukakan oleh Mihardja (2009), tingkat pendidikan dapat mempengaruhi kemampuan dan pengetahuan seseorang dalam menerapkan pola hidup sehat, salah satunya upaya untuk mencegah DM.

Hasil penelitian menunjukkan terdapat 22 responden $(59,0 \%)$ tidak bekerja. Pasien DM tersebut sebagian besar merupakan ibu rumah tangga dan pensiunan. Aktivitas fisik yang dilakukan oleh orang yang tidak bekerja seperti pensiunan dan ibu rumah tangga kemungkinan besar lebih sedikit dibandingkan dengan orang yang memiliki aktivitas atau pekerjaan diluar rumah. Hasil penelitian ini sejalan dengan penelitian yang dilakukan oleh Trisnawati (2013), pekerjaan seseorang dapat mempengaruhi tingkat aktivitas fisik yang dilakukan. Aktivitas fisik mengakibatkan insulin semakin meningkat sehingga kadar gula darah akan berkurang. Jika insulin tidak mencukupi untuk mengubah glukosa menjadi energi maka akan timbul DM. Hasil penelitian tersebut sejalan dengan penelitian yang dilakukan oleh Ramadhanisa, Larasati dan Mayasari (2013), terdapat 96,3\% responden dalam penelitian tersebut memiliki aktivitas yang kurang dan memiliki kadar HbA1c yang buruk. Penelitian yang dilakukan oleh Hartono (2012), ditemukan sebagian besar 
pasien DM tipe II bekerja sebagai pegawai kantor termasuk BUMN, PNS, TNI dan POLRI. Pekerjaan mempengaruhi aktivitas fisik seseorang, selain itu mengkonsumsi makanan yang tinggi kalori dan tidak melakukan olahraga teratur, dapat meningkatkan resiko obesitas. Faktor pencetus yang lain dikemukakan oleh Suiraoka (2012), bahwa kemajuan teknologi dan kemapanan ekonomi membuat gaya hidup seseorang menjadi berubah, misalnya orang lebih cenderung pasif dalam bergerak. Pendapat tersebut mendukung penelitian yang dilakukan oleh Sunjaya (2009), diketahui bahwa orang yang memiliki aktivitas fisik yang ringan memiliki risiko 4,36 kali lebih besar untuk menderita DM dibandingkan dengan orang yang memiliki aktivitas yang sedang dan berat.

Hasil penelitian menunjukkan terdapat 16 responden $(43,0 \%)$ memiliki penghasilan dibawah UMR Kabupaten Kendal. Pendapat Fattah (2006), mengatakan bahwa kemampuan ekonomi masyarakat akan menentukan tingkat partisipasi dalam pembangunan misalnya partisipasi dalam menjaga kesehatan. Pendapat tersebut mendukung hasil penelitian yang dilakukan oleh Izzati, Wisnatul dan Nirmala (2015), mayoritas pasien DM berusia lebih dari 60 tahun $(56,3 \%)$, pada usia tersebut terjadi perubahan fisik sehingga responden tidak dapat beraktivitas seperti biasa dan berdampak pada masalah ekonomi.

Hasil penelitian menunjukkan terdapat 23 responden $(62,1 \%)$ memiliki status perkawinan yaitu menikah. Penelitian ini sejalan dengan penelitian yang dilakukan oleh Sari, Thobari dan Andayani (2011), seseorang yang terikat dalam status pernikahan memiliki kualitas hidup yang lebih baik dibandingkan seseorang yang tidak terikat dalam status pernikahan. Seseorang yang berstatus menikah akan mempunyai harga diri yang lebih tinggi dan mempunyai sumber koping yang adekuat dari pasangannya sehingga dapat lebih mengembangkan koping yang adaptif terhadap stressor yang muncul. Penelitian tersebut mendukung penelitian yang dilakukan oleh Putri, Yeni dan Handayani (2013), didapatkan data bahwa $76,2 \%$ responden atau pasien DM yang memiliki peran keluarga yang baik, memiliki gula darah yang terkendali, sedangkan $23,8 \%$ pasien DM memiliki gula darah yang tidak terkendali. Penelitian yang dilakukan oleh Coffman (2008), pasien DM akan mendapatkan berbagai dukungan sosial yang dapat meningkatkan kepercayaan diri. Dukungan sosial yang utama adalah dukungan dari keluarga dan dukungan yang lain didapatkan dari teman dan petugas kesehatan.

Hasil penelitian menunjukkan terdapat 23 responden $(62,0 \%)$ telah menderita DM selama lebih dari lima tahun. Pendapat Rahmat (2010), mengatakan bahwa pasien DM dapat mengalami penurunan kualitas hidup setelah menderita DM minimal selama satu tahun, hal ini disebabkan karena dalam rentang waktu tersebut pasien telah mengalami dan merasakan berbagai perubahan atau keluhan fisik dan psikis akibat penyakitnya tersebut. Pendapat tersebut tidak sejalan dengan penelitian yang dilakukan oleh Izzati dan Nirmala (2015), terdapat 87,5\% responden telah menderita DM selama lebih dari lima tahun. Lama waktu menderita DM tersebut menyebabkan munculnya berbagai pengalaman misalnya munculnya komplikasi DM, sehingga pasien DM tersebut termotivasi untuk patuh menjalankan diet DM, mengurangi stres, minum obat, sehingga tidak mengalami kenaikan kadar gula darah.

Responden dalam penelitian sebagian besar mengalami stres ringan yaitu sebanyak 17 responden $(46,0 \%)$. Hal tersebut dapat diketahui dari pertanyaan kuesioner DASS yang telah digunakan dalam penelitian ini, terdapat $89,1 \%$ pasien DM sulit sabar dalam menghadapi gangguan terhadap hal yang sedang dilakukan. Karakteristik pasien DM dalam 
penelitian ini seperti usia, pekerjaan, dan tingkat ekonomi dapat menjadi pemicu hal tersebut. Usia pasien DM dalam penelitian ini mayoritas berusia 25-60 tahun, pada usia tersebut seseorang dapat memiliki kemampuan kontrol diri dalam menghadapi gangguan atau masalah dikehidupan sehari-hari yang lebih baik tetapi tidak menutup kemungkinan bahwa ada beberapa orang dengan usia yang lebih dewasa atau lebih tua justru memiliki kontrol diri yang kurang baik sehingga dapat muncul tanda gejala gangguan psikologis seperti stres. Sebagian besar pasien DM juga tidak bekerja dan memiliki tingkat ekonomi yang rendah, hal ini dapat memicu munculnya ketidaksabaran atau kontrol diri yang buruk dalam menghadapi suatu gangguan. Selain itu, terdapat $86,4 \%$ pasien DM merasa dirinya menjadi marah karena hal-hal yang sepele, $81 \%$ cenderung bereaksi berlebihan terhadap suatu situasi, $78,3 \%$ mudah kesal, $83,7 \%$ sangat mudah marah, $83,7 \%$ sulit tenang setelah sesuatu membuatnya menjadi kesal, dan $89,1 \%$ sulit untuk sabar dalam menghadapi gangguan. Beberapa pertanyaan kuesioner tersebut menggambarkan bahwa pasien DM mengalami kondisi emosional yang buruk. Hasil penelitian ini didukung oleh penelitian yang dilakukan oleh Widakdo dan Besral (2013), terdapat 24-47\% pasien penyakit kronis seperti DM, tumor, dan kanker mengalami gangguan mental emosional. Goleman (2006), berpendapat bahwa kemampuan untuk memantau perasaan dari waktu ke waktu merupakan hal yang penting bagi wawasan psikologi dan pemahaman diri pada seseorang untuk mencapai kesejahteraan emosi. Aditya (2015), memperkuat pendapat dari Goleman yaitu ketenangan jiwa yang dipadukan dengan proses berpikir yang baik menggunakan "kepala dingin" merupakan solusi bagi orang yang memiliki masalah emosi. Kedua hal tersebut akan memberikan kontrol pada diri, jika mampu mengontrol dan mengatasi emosi, bahkan mengenali penyebab emosi yang dialami, maka akan lebih terampil untuk mengendalikan emosinya tersebut. Ketika seseorang mampu mengenali emosinya dengan baik, maka orang tersebut akan mampu berinteraksi baik dengan orang lain disekitarnya.

\section{Simpulan dan Saran}

Berdasarkan penelitian yang sudah peneliti lakukan maka, peneliti dapat menarik kesimpulan bahwa, karakteristik pasien DM dalam penelitian ini sebagian besar berusia 25-60 tahun, berjenis kelamin perempuan, Sekolah Menengah Atas, tidak bekerja, memiliki penghasilan kurang dari UMR Kabupaten Kendal, menikah, dan lama menderita DM lebih dari lima tahun, dan sebanyak $46,0 \%$ mengalami stres ringan.

Peneliti memberikan saran kepada klinik praktik untuk dapat mengidentifikasi stres yang dapat dialami oleh pasien DM secara dini sehingga stres yang dialami dapat segera diatasi, karena stres yang tidak segera ditangani dapat menyebabkan depresi. Pasien yang mengalami stres dapat memberikan terapi atau pengobatan yang tepat secara dini, sehingga stres yang dialami oleh pasien DM dapat segera ditangani

\section{Daftar Pustaka}

Aditya Z, C. (2015). Berbagai terapi jitu atasi emosi sehari-hari. Yogyakarta: Flash Books.

Baradero, M., Dayrid, M.W \& Siswadi, Y. (2009). Pasien gangguan endokrin. Jakarta: EGC.

Coffman, M.J. (2008). Effects of tangible social support and depression on diabetes self-efficacy. Journal of Gerontological Nursing.

Fattah, Nanang. (2006). Ekonomi dan pembiayaan pendidikan. Bandung: Remaja Posdakarya. 
Global report on diabetes mellitus. (2016). WHO Library Cataloguing-inPulication Data. World Health Organization.

Goleman, D. (2006). Emotional intelligence. Jakarta: Gramedia Pustaka Utama.

Hamdi, Asep Saepul, Baharuddin. (2014). Metode penelitian kuantitatif aplikasi dalam pendidikan. Yogyakarta. Deepublish.

Hartono, R (2012), Hubungan asupan serat larut (soluble dietary fiber) dan aktivitas fisik dengan kejadian diabetes melitus tipe II pasien rawat jalan di RSUD Dr. Rubini Mempawah Kalimantan Barat. http://old.fk.ub.ac.id. (Diakses pada tanggal 4 Februari 2017).

Hasanuddin, Kristofel, Mahatrisni, Winasis \& Satrio (2011). Anxieties/desires: 90 insights for marketing to youth, women, netizen. Jakarta: PT Gramedia Pustaka Utama.

Izzati, Wisnatul \& Nirmala. (2015). Hubungan tingkat stres dengan peningkatan kadar gula darah pada pasien diabetes mellitus di wilayah kerja Puskesmas Perkotaan Rasimah Ahmad Bukittinggi. STIKes Yarsi Sumatera Barat Bukittinggi. http://ejournal.stikesyarsi.ac.id.

(Diakses pada tanggal 25 November 2016).

Jelantik, I. M. G. \& Haryati, E. (2014). Hubungan faktor umur, jenis kelamin, kegemukan dan hipertensi dengan kejadian DM tipe 2 di wilayah kerja Puskesmas Mataram. Jurnal Media Bina Ilmiah. http://lpsmataram.com. (Diakses pada tanggal 7 Januari 2017).
Kristiana, F. (2012). Awas pankreas rusak penyebab diabetes. Jakarta: Cerdas Sehat.

Lapau, Buchari. (2012). Metode penelitian kesehatan: Metode ilmiah penulisan skripsi, tesis, dan disertasi. Jakarta: Yayasan Pustaka Obor Indonesia.

Miharja, L., (2009). Faktor yang berhubungan dengan pengendalian gula darah pada penderita diabetes melitus di perkotaan Indonesia. Majalah Kedokteran Indonesia.

Misnadiarly. (2006). Diabetes mellitus: gangren, ulcer, infeksi. Mengenal gejala, menanggulangi, dan mencegah komplikasi. Jakarta: Pustaka Populer Obor.

Nursalam, Kurniawati D. N. (2007). Asuhan keperawatan pasien terinfeksi HIV/AIDS. Jakarta: Salemba Medika.

Notoatmodjo, Soekidjo. (2007). Promosi kesehatan dan ilmu perilaku kesehatan. Jakarta: Rineka Cipta.

(2012). Metode penelitian kesehatan. Edisi Revisi. Jakarta: Rineka Cipta.

Perkeni. (2011). Konsensus pengelolaan dan pencegahan diabetes mellitus 2 di Indonesia. Jakarta.

Profil Dinas Kesehatan Provinsi Jawa Tengah 2015. Triwulan 3 tahun 2015. www.dinkesjatengprov.go.id. (Diakses pada tanggal 23 September 2016).

Profil Kesehatan Indonesia 2008. (2009). Jakarta: Departemen Kesehatan Republik Indonesia.

Purnamatari, W. (2011). Beberapa faktor yang berhubungan dengan 
keteraturan pemeriksaan kadar gula darah penderita diabetes melitus tipe 2 di RSUD Dr. Moewardi Surakarta. Skripsi Fakultas Ilmu Kesehatan Universitas Muhammadiyah Surakarta. http://eprints.ums.ac.id. (Diakses pada tanggal 4 Februari 2017).

Putri, Yeni \& Handayani. (2013). Hubungan peran keluarga dengan pengendalian kadar gula darah pada pasien diabetes melitus di wilayah kerja Puskesmas Pauh Padang. Ners Jurnal Keperawatan Volume 9, Nomor 2. http://jurnal.fkep.unand.ac.id. (Diakses pada tanggal 4 Februari 2017).

Rahmat, W. P. (2010). Pengaruh konseling terhadap kecemasan dan kualitas hidup pasien DM di Kecamatan Kebakkramat. Tesis. eprints.uns.ac.id. (Diakses pada tanggal 8 Januari 2017).

Ramadhanisa, Aqsha, Larasati dan Mayasari (2013). Hubungan aktivitas fisik dengan kadar HbAlc pasien diabetes melitus tipe II di Laboratorium Patologi Klinik RSUD Dr. H Abdul Moeloek Bandar Lampung. Http//httpjuke.kedokteran.unila.ac.i d. (Diakses pada tanggal 5 Februari 2017).

Reno, Gustaviani (2006). Diagnosis dan klasifikasi diabetes melitus, buku ajar ilmu penyakit dalam, Jilid III,Edisi IV. Jakarta: Pusat Penerbitan Ilmu Penyakit Dalam Fakultas Kedokteran Universitas Indonesia.

Rfyy, C.D. \& Singer, B.H. (2006). Best news yet on the six-factor model of well being. Social Science Research.
Riset Kesehatan Dasar Riskesdas 2013. http://www.depkes.go.id. (Diakses pada tanggal 24 September 2016).

Safitri, Inda Nofriani. (2013). Kepatuhan penderita diabetes mellitus tipe II ditinjau dari locus of control. Jurnal Ilmiah Psikologi Terapan Volume 01 Nomor 02. Fakultas Psikologi Universitas Muhammadiyah Malang. http://ejournal.umm.ac.id. (Diakses pada tanggal 4 Februari 2017).

Sari, Susanti \& Sukmawati. (2014). Peran keluarga dalam merawat pasien diabetik di rumah. Jurnal Ners LENTERA.

Sari, R. M., Thobari, J.A., \& Andayani, M. T. (2011). Evaluasi kualitas hidup pasien DM tipe 2 yang diterapi rawat jalan dengan anti diabetik oral di RSUP dr. sardjito. Jurnal Manajemen dan Pelayanan Farmasi. http://jmpf.farmasi.ugm.ac.id. (Diakses pada tanggal 7 Januari 2017).

Semiardji, G. (2009). Stres emosional pada penyandang diabetes. Penatalaksanaan diabetes melitus terpadu edisi kedua. Jakarta: Balai Penerbit FKUI.

Sholichah, Diah Rustiani. (2009). Hubungan antara dukungan sosial dengan derajat depresi pada penderita diabetes mellitus dengan komplikasi. Skripsi. Surakarta. Fakultas Kedokteran Universitas Sebelas Maret. http://eprints.uns.ac.id. (Diakses pada tanggal 26 September 2016).

Sunjaya, I. N. (2009). Pola konsumsi makanan tradisional Bali sebagai faktor risiko diabetes melitus tipe 2 di Tabanan. Jurnal Skala Husada. 
Suiraoka I, P, (2012). Penyakit degeneratif, mengenal, mencegah, mengurangi risiko 9 penyakit degeneratif. Yogyakarta: Nuha Medika.

Sutedjo. (2010). 5 strategi penderita diabetes mellitus berusia panjang. Yogyakarta: Kanisius.

Tamara, Bayhakki \& Nauli (2014). Hubungan antara dukungan keluarga dan kualitas hidup pasien diabetes mellitus tipe II di RSUD Arifin Achmad Provinsi Riau.

Taylor, C (2008). Gula darah dan menopause kenali tanda awal ketidakseimbangan menopause. http://ezinearticles.com. (Diakses pada tanggal 7 Januari 2017).

Tjokoprawiro, Askandar. (2011). Hidup sehat bersama diabetes: Panduan lengkap pola makan untuk penderita diabetes. Jakarta: PT Gramedia Pustaka Utama.

Trisnawati, S., Setyorogo, S., (2013). Faktor risiko kejadian diabetes melitus tipe II di Puskesmas Kecamatan Cengkareng Jakarta Barat Tahun 2012. Jurnal Ilmiah Kesehatan.

Widakdo, G., Besral. (2013). Efek penyakit kronis terhadap gangguan mental emosional. Kesmas, Jurnal Kesehatan Masyarakat Nasional Vol. 7, No. 7. Jakarta. Universitas Indonesia.

Yusra, Aini. (2010). Hubungan antara dukungan keluarga dan kualitas hidup pasien DM tipe 2 di Poliklinik Penyakit Dalam Rumah Sakit Umum Pusat Fatmawati Jakarta. Tesis. www.lontar.ui.ac.id. (Diakses pada tanggal 7 Januari 2017).

Zainuddin, Wasisto \& Herlina. (2015). Hubungan stres dengan kualitas hidup penderita diabetes mellitus tipe

http://download.portalgaruda.org. (Diakses pada tanggal 7 Januari 2017). 